\author{
Зінаӥда СВЯЩЕНКО, \\ orcid.org/0000-0001-5845-3115 \\ доктор історичних наук, професор кафедри \\ всесвітньої історії та методик навчання

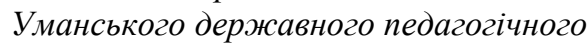 \\ університету імені Павла Тичини \\ (Украӥна, Умань) \\ szv09@meta.ua \\ олена СКРИПНИк, \\ orcid.org/0000-0003-1904-3468 \\ кандидат історичних наук, дочент кафедри \\ всесвітньої історії та методик навчання

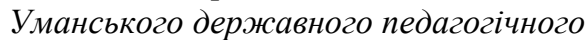 \\ університету імені Павла Тичини \\ (Украӥна, Умань) \\ olena-skripnik@meta.ua
}

\title{
ВПЛИВ ПОЛІТИКИ КРИМСЬКОГО ХАНСТВА НА ІСТОРИЧНИЙ РОЗВИТОК УМАНЩИНИ (XV - СЕРЕДИНА ХVII СТ.)
}

У статті проаналізовано вплив агресивної політики Кримського ханства на історичний розвиток земель Уманщини у XV - середині XVII cm. Зазначається, щзо через окраӥнне положення землі Уманщңини зазнавали періодичних спустошливих набігів кримських татар, саме через ії територію проходив відомий Чорний шлях, яким татари здійснювали набіги на украӥнські землі. Разом з тим, з 30-х рр. XVII ст. з боку ханства спостерігається поява намірів до співробітнищтва, щуо було викликано змінами в суспільноекономічному житті изього державного утворення. Наголошується, щзо не зважаючи на напади татар у першій половині XVI cm. починається новий період заселення території краю так званими уходниками, вільними добичниками козаками, які йшли з Волині, Київщини Полісся та Білорусії.

Ключові слова: Уманщина, Кримське ханство, походи, колонізачія, порубіжжя.

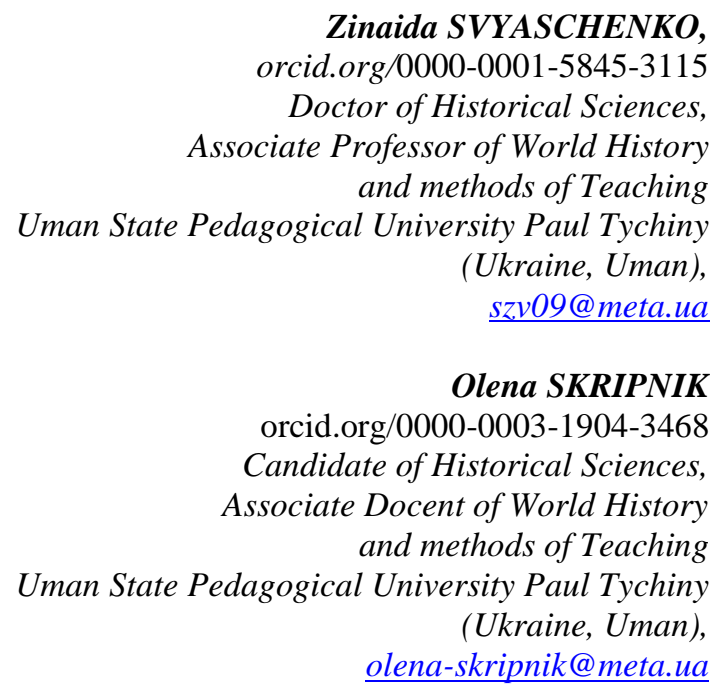

THE INFLUENCE OF THE POLITICS OF THE CRIMEAN KHANATE ON THE HISTORICAL DEVELOPMENT OF UMANSHCHINA (XV - MIDDLE OF XVII CENTURIES) 
The article analyzes the influence of the aggressive policy of the Crimean Khanate on the historical development of the lands of Uman region in the XV - mid XVII centuries. It is noted that due to the marginal position of the land of Uman region, Crimean Tatars were subjected to periodic devastating raids.

The purpose of the proposed study is to analyze the impact of the aggressive policy of the Crimean Khanate on the historical development of the lands of Uman in the XV - mid XVII centuries, to investigate the colonization processes that took place in the region during the period under study.

The periodicity and nature of Tatar campaigns on Ukrainian lands in general and Uman region in particular are analyzed. The Tatar roads that passed through the territory of the region, namely the Black and Kuchman, as well as the defensive line that passed through the lands of Uman region are characterized.

However, it is noted that since the 30's of the XVII century on the part of the Khanate there is an intention to cooperate, which was caused by changes in the socio-economic life of this state formation. Changes in relations with Crimea had a significant positive impact on the population of Uman. The immediate danger of destructive Tatar raids decreased, the local population's trade with the southern neighbor, with its traditionally rich goods, expanded, and the dairy industry began, based on the delivery of salt from the shores of the Black Sea. But perhaps the most important thing was that the local population began to develop more and more intensively the fertile lands of the Steppe, spreading further and further south its influence.

It is emphasized that in the first half of the XVI century, despite the attacks of the Tatars, a new period of settlement of the territory of Uman begins. From Volhynia, Kyiv region, Polissya and Belarus came vagrants, free miners, "tributes", Cossacks. This colonization movement in the Uman region is connected with the general nature of the population of the Dnieper region, which was already taking place at that time. The population of the newcomer unites with the Cossacks who were in the area.

It is concluded that the Turkish-Tatar aggression posed a mortal threat to the Ukrainian people of extermination, loss of economic and economic independence. And perhaps the border population suffered the most. It was here, in the Uman region, that the invasion of the Tatars and Turks was accompanied by the most brutal destruction of towns and villages, the extermination and exile of large masses of the population. The population played a decisive role in repelling the Turkish-Tatar attacks Uman region. Engaged in farming, cattle-breeding, fishing, hunting, handicrafts, founding new hamlets and villages, creating new and raising destroyed cities from the ruins, it was at the same time ready to repel the Turkish-Tatar attacks. It became the basis of the Cossacks, overgrown with refugees from different lands.

Key words: Uman region, Crimean Khanate, campaigns, colonization, borderlands.

Постановка проблеми. Починаючи з 60-70-x pp. XV ст. і до кінця XVII ст. на становище населення Уманщини визначальною мірою почало впливати Кримське ханство Саме це державне формування із самого початку свого існування зайняло агресивну позицію щодо сусіднього українського населення, вирішальною мірою вплинуло на стан життя всієї України, і, особливо, Уманщини, яка стала найближчим порубіжжям.

Аналіз досліджень. Про роль і значення кримсько-татарської агресії для долі українського народу є чимало досліджень, у яких висвітлюється характер взаємин з Кримським ханством в ці часи. Про геополітичні устремління Золотої Орди, Туреччини та Росії, які проявлялися через посилення або послаблення ролі Кримського ханства в південній Україні, писав у своїх дослідженнях М. Грушевський (Грушевський, 1993), який висвітлював ці події через показ державницьких інтересів Росії. 
Про взаємостосунки українських земель з Кримом пишуть практично всі дослідники історії України та українського козацтва. Існує і спеціальна дослідницька література, серед якої можна виділити праці: О. Апанович (Апанович, 1961), В. Вишневського (1930), О. Сфименко (Єфименко, 1919), Я. Кісь (Кісь, 1986), В. Панашенко (Панашенко, 1989), А. Якобсона (Якобсон, 1973) та ін. Але названі публікації мають загальноісторичний характер, а між тим, саме регіональні дослідження найбільш яскраво ілюструють загальні тенденції. Варто зазначити, що землі Уманщини у період, що досліджується перебувають в центрі уваги істориків-краєзнавців Т. Кузнець (Кузнець, 2000), I. I Кривошеї та Ір. І. Кривошеї (Кривошея, Кривошея, 2000), але саме заявлена у статті проблема немає розробок конкретно історичних, регіональних.

Мета статті. Метою дослідження $є$ проаналізувати вплив агресивної політики Кримського ханства на історичний розвиток земель Уманщини у XV середині XVII ст., дослідити колонізаційні процеси, які мали місце на території краю у період, що досліджується.

Виклад основного матеріалу. Намагаючись покращити свої стосунки 3 Кримом, литовський князь Олександр погоджувався на відновлення щорічних «дарунків», данини, як це було за часів Золотої Орди, причому за рахунок українських земель «зі своїх людей і з князівських, і з панських, і з боярських у землі Київській, Волинській і Подільській $з$ кожної голови... по три гроши давати щороку» (Історія України, 1995: 118).

Така позиція владних структур Литви щодо татарських походів, захисту населення Уманщини не могла не стимулювати подальших агресивних набігів на ці землі.

Особливо складне становище на Уманщині склалося у 80-і pp. XV ст. - час загострення конфлікту між Росією та Литвою. Росія уклала союз із МенгліГіреєм, який у 1482 р. напав на південно-українські землі, захопив Київ. На Уманщині було захоплено величезну кількість полонених. Литовський князь Казимир залишив напризволяще цю частину своєї держави, аби не псувати взаємостосунків з Кримським ханством. Літописець описує цю подію так: «... 
по слову великого князя Ивана Васильевича... Менгли-Гирей... со всею силою своею и град Киев взя и землю учиниша пусту Киевскую...» (Полное собрание, 1962: 330).

Уманщина в цей час страждала не лише від набігів кримських татар та турків. В другій половині XVI ст. на південно-українські землі переселилася Мала Ногайська орда 3 прикаспійських степів. Вона потрапила під повну васальну залежність від Кримського ханства. Після розпаду Малої Ногайської орди у 20-і pp. XVII ст. утворилися Білгородська, Джамбуйлуцька, Едисанська та Едичкульська орди, які зберігали васальну залежність від Криму. Населення цих орд займалося скотарством, торгівлею, частково землеробством.

Особливо відзначалася Едисанська (Очаківська) орда, яка займала землі між Дніпром, Південним Бугом і Дністром - від узбережжя Чорного моря до річки Кодими, тобто у безпосередньому сусідстві з Уманщиною. Отже, місцеве населення території Уманщини зазнавало значного лиха і від походів союзників кримських татар - степових орд. І хоч в історичній хроніці під 1497 р. оповідається як князі Михайло й Констянтин Острозькі «поразивши на голову татар на берегах р. Сороки, в Брацлавшине, преследовали их до истоков р. Умы й тут истребили всех до одного» (Супральская рукопись, 1836: 144 ), все ж населення краю дуже страждало від наскоків південних сусідів.

Величезна територія України по Південному Бугу, по нижній і середній течії Дніпра дуже потерпала від цих нападів. Населення старалося селитися навколо замків - Києва, Брацлава, Вінниці, Житомира, Черкас, Канева, Чернігова та ін. Проте ці замки були в поганому стані і не могли бути надійним захистом від татар. Незважаючи на те, що литовські князі почали сплачувати кримським ханам щороку велику грошову данину, татари не переставали нападати на українські землі. I головний тягар оборони українських земель від турецько-татарської агресії ліг на плечі українського люду.

Як бачимо, в цей час вперше близька назва до топоніму Уманщина згадується в джерелах під 1497 р., коли князь Константин Острозький переслідував татар від р. Сороки на Брацлавщині і остаточно розбив їх в 
місцевості біля витоків р.Уми. В цій битві загинув син кримського хана Ахмат (на Уманщині в XVI ст. вже існувало селище, а пізніше фортеця, Охматів) (К. И. Т-ый, 1888: 391). В 1497-1500 рр. князь Острозький був намісником брацлавським, звенигородським та вінницьким, а отже контролював i Уманщину (Яковенко, 1993: 90).

Окремо стоїть питання про періодичність походів татар на українські землі. «Володарі Татарії мали звичай йти воювати двічі на рік або в усякому разі хоча б один раз. Але подібні дії слід було б скоріше називати розбоєм, ніж війною» зазначав Е. Д. де Асколі (Описание..., 1992: 123).

В. Антонович вважав, що такі напади здійснювались частіше, він писав: «Ежегодно, а иногда несколько раз в год Брацлавщину посещали злые гости и естественно, что на прохожей дороге хищников трудно было усидеть мирному земледельческому населению» (Антонович, 1888: 5), як бачимо ці слова відносяться до території історичної Уманщини, на землі якої, можливо, татари здійснювали набіги набагато частіше ніж на інші. Доказом цього можуть бути також слова В. Антоновича, який писав: «Брацлавщина притом подвергалась гораздо более чувствительным ударам со стороны татар, чем Украина приднепровская: она не только сама по себе служила целью для хищнических набегов, но по ней орда должна была проходить каждый раз, когда загоны её устремлялись на Волынь, Червоную Русь или южную Польщу» (Антонович, 1888: 5).

Населення південних окраїн України жило в постійній напрузі. Але i жителі більш віддалених земель не могли почувати себе в безпеці. Про це говорять факти, які наводять дослідники. В 1505 р. татари пограбували не лише Київщину, але і Волинь і навіть Холмську і Белзьку землі, дійшовши до Вісли. В 1502, 1508 і 1509 pp. спустошене Поділля та Галичина, а в 1508, 1512 і 1517 pp. - Волинь. В 1524 р. кочовики зруйнували Львівську і Подільську землі, а в 1534 i 1549 pp. знову вторглися на Волинь. В цей же час Південна Київщина i Переяславщина зазнавали набігів татар щорічно (История Украинской ССР, 1981: 80). 
В 1551, а за Київським літописом - в 1550 р. (Київський літопис, 1989: 285) військами Давлет-Гірея було зруйновано Брацлав, замок спалено, а населення забрано в полон (Архив Юго-Западнои России, 1890: 16-17). Серед причин захоплення Брацлавського замка вказуються також його часткове запустіння, тому що після заснування замка великим князем Олександром у 1497 р. (Сборник летописей, 1888: 285), ніяких ремонтних робіт там не проводилось. Та вже наступного 1552 р. Сигізмунд Август полагодив замок і розмістив у ньому військовий гарнізон (Архив Юго-Западнои России, 1890: 80-81).

Не отримуючи серйозної допомоги 3 боку Литви, а потім Польщі, населення Уманщини організовує власні козацькі загони, які дають відчутну відсіч нападникам.

На українські землі татари ходили вибраними, витоптаними кінськими копитами шляхами: Чорним, Кучманським, Молдавським або Покутським та Муравським. Ці шляхи проходили через вододіли. «Іноді малопомітні, різними невизначеними, змінюваними рукавами і поворотами, часто аж надто широкі на два польоти випущеної 3 лука стріли»- так описували їх сучасники (Описание..., 1992: 130).

Головний $з$ цих шляхів, що був найбільш вторований татарськими кіньми, відомий в історії під назвою «Чорний шлях» («Dia nigra», «Джорна іслях») (Чабан, 1999: 10). Він розпочинався від Перекопу, йшов до Таванського броду, де переходив на правий берег Дніпра, далі йшов до Інгульця, мимо Чорного лісу повертав на північний захід. Тут, біля Чорного лісу, збиралися татарські війська для своїх подальших походів. Трохи далі, біля Лебединського лісу (на Шполянщині), Чорний шлях розділявся на два рукави.

Перший прямував на Київ через землі Звенигородщини, межиріччям Гнилого Тікича і Росі, оминаючи Лисянку і Таращу, другий - поміж верхів'ям рік, що вливалися з одного боку в Синюху, а з другого - в Тясмин й Вільшану, прямував аж на Волинь, Прикарпаття. Власне, i той і другий рукави Чорного шляху проходили через землі Уманщини з півдня та заходу, а точніше від Чорного лісу через броди на р. Синюсі в районі Торговиці, потім повз Умань, 
залишаючи місто з правої руки, на Монастирище, Кальник, Вінницю і далі на захід (Кащенко, 1991: 60-61; Волошенко, 1995: 18), й дуже часто татари повертали на ці землі, грабуючи все на своєму шляху, аж до того часу, коли місцеві жителі не почали давати відсіч агресорам.

За відомостями дипломата Бжевського - сучасника тих подій, що дійшли до нас, - лише за два роки (у 1556-1567 рр.) під час нападів на українські землі татари пограбували і зруйнували 327 міст та сіл, при цьому спалили величезну кількість збіжжя, забрали більше 64 тисяч корів, 175 тисяч овець, 9 тисяч верхових коней, понад 9 тисяч місцевого населення взяли в полон (Кісь, 1986: 134-136).

Від Чорного шляху біля Чорного лісу відгалуджувався Кучманський шлях. Дослідник М.Горн вказував, що протягом 1605-1663 рр. татари нападали, йдучи цим шляхом, 27 разів, в різні пори року, але найчастіше влітку. Татари в ці роки, як пише дослідник, знищили 320 міст та сіл, вбили та забрали полоненими біля 130 тисяч осіб українського населення (Османская империя, 1984: 23-24).

У звязку з цим актуальним є риторичне запитання сучасника тих подій: «хто з істориків підрахував, скільки десятків тисяч наших братів взяли татари в той чи інший час, хто склав до купи цілу суму і при цьому підрахував приплід, який могли б дати ті схоплені, мешкаючи у нас і збільшуючи кількість нашого народу? Хоча кажуть, що кількість ця бесконечна, а я не знаю, чи вистане цифр, щоб вирахувати таку велетенську кількість людей, яку втратив наш народ через татар і ще втрачає». За твердженням істориків, втрати українського населення як мінімум становили 2,5 млн. убитих та полонених (Історія України, 1997: 66).

Ситуація на українських землях покращилася, коли завершилося спорудження Росією на початку XVII ст. Білгородської оборонної лінії, яка повинна була захищати від турецько-татарських загарбників північні землі. Ця безперервна лінія довжиною понад 300 верст, 3 центром у Білгороді, складалася 3 системи укріплень і перерізала головні шляхи ханських походів. Укріплені міста зв'язувалися між собою системою фортифікацій, що складалися із засік, 
земляних валів з частоколом, жилих і стоялих укріплень, 3 караульними баштами. Збудовані укріплення доповнювалися природними перепонами (річки, болота, яри).

На південь від укріплень у степу засновувалися станиці, роз'ізди і постійні сторожі. Це були аванпости, що несли розвідувально-сторожову службу i своєчасно попереджували про пересування татар. Натикаючись на цю могутню оборонну лінію, турецько-татарські загони вимушені були повертати на Україну, визискуючи за невдалий похід з місцевого населення. Про такі сторожі на території Уманщини, писав О.Терлецький, вони знаходились на ріках, які впадали в Південний Буг: з лівої сторони - на Синиці, а з правої - на Саврані та в інших місцях. По головних татарських шляхах теж були розставлені сторожі, які виходили із сусідніх поселень (Терлецький, 1930: 47). Як писав I.Молчановський «... благодаря постоянной грозе со стороны татар, Подолье представляло из себя военный лагерь, всегда находившийся в готовности к войне» (Молчановский, 1886: 246).

Саме тут, на Уманщині, вторгнення татар та турків супроводжувалося найжорстокішим розоренням міст та сіл, винищенням і вигнанням у рабство великих мас населення. «Наслідком тих постійних татарських наїздів, - писав О.Терлецький, - опустіла Переяславщина, полуднева Чернігівщина, полуднева й середня Київщина, Брацлавщина й східне Поділля. Словом, українське населення не тільки відогнано від берегів Чорного моря, але ціла степова й передстепова Україна стали пустинею» (Терлецький, 1930: 45).

Польські історики в кінці XVI ст. відмічали, що на південь і схід від Брацлава - а саме тут Уманщина - були і села, i дорога, i замки і городища, щоправда - зруйновані. Так, Й. Верещинський писав: «Що Україна колись рясніла багатствами, краще всього видно по спустошених церквах. Замки, або вірніше, городища - такі міцні, що коли б укріпити їх баштами, то вони зробились би неприступними...» (Стороженко, 11895: 58-59). «На південь і схід Брацлавля простягнулась пустиня, дорога порівняно безпечна $є$ тільки до Вінниці. Колись ішов прямий шлях до Черкас, Канева і Києва, але на запитання 
ревізора про цю дорогу місцеві люди відповідали, що, починаючи від Брацлавля, всі села, через які проходив колишній шлях, запустіли "від поганства"; але коли відбудувати замок Звенигородський i заселити замки людьми пенежними, які б жили там постійно зимою і літом, тоді б від татар зробилось би безпечніше, і села могли б знов осісти» (Архив Юго-Западнои России, 1890: 56). Писалось це, як було сказано вище, ще в кінці XVI ст. якщо тоді на Уманщині були зруйновані замки і села, то зруйнували їх десь на початку XVI ст. або в кінці XV ст. а до того тут вирувало життя, ще й, як писав Й. Верещинський, досить заможне. Кримські татари настільки часто і жорстоко нападали на Уманщину, що вона швидко перетворилася в «Гуманську пустиню». Це ж констатує і В. Антонович, який писав, що «После татарского разорения...Брацлавщина, наравне со всею южною окраиною литовскорусского государства, пришла в совершенное почти запустение» (Антонович, 1888: 1).

Дослідники, спираючись на різноманітні джерела, наводять дані, коли за двотижневий похід татари захоплювали по 50 і більше тисяч мирного населення. Роки 1515, 1537, 1575, 1589, 1593, 1640, 1666, 1667, 1671 позначені найстрашнішими набігами на південні українські землі. Тоді татари забирали по 5, 8, 16 і навіть 55 тисяч християн (Чумак, 1992).

Слід відзначити, що з часом ситуація у взаємовідносинах козацтва та Кримського ханства починає докорінно мінятися. Розпочинаючи з 30-х рр. XVII ст., спостерігається поява з боку ханства намірів до співробітництва. Це було викликано змінами в суспільно-економічному житті цього державного формування.

Перш за все, тут відбувається перехід до осілого землеробства, кочівництво відходить на другий план. Наростає стремління кримських феодалів до торгових зв'язків з Україною. Це зумовлюється тим, що місцеві селяни не могли забезпечити населення продуктами харчування. Ряд козацьких гетьманів починає також іти на зближення, шукати зв’язків 3 кримськими 
татарами, для організації боротьби з агресивними устремліннями Польщі та Pociï.

Зміни взаємостосунків з Кримом мали значний позитивний вплив на населення Уманщини. Зменшується безпосередня небезпека руйнівних татарських набігів, розширюється торгівля місцевого населення 3 південним сусідом, 3 його традиційно багатими товарами, розпочинається чумацький промисел, в основі якого була доставка солі з берегів Чорного моря. Та чи не найголовнішим було те, що місцеве населення почало все інтенсивніше освоювати родючі землі Степу, поширюючи все далі на південь свій вплив. Хоча загроза нападів з боку Криму ще тривалий час висіла над Україною. Ці процеси особливо зримо постали в середині XVII ст., тобто на значно пізніших етапах розвитку Уманщини.

Саме в цей час спостерігається наявність численного тюркського елемента в складі місцевого населення. Н. Яковенко зазначає, що його загальна чисельність в складі київсько-брацлавських феодалів становила близько третини населення (Яковенко, 1993: 170). Н. Яковенко пояснює це тим, що «українське пограниччя, яке тяглося довгим пасмом охоплюючи пониззя між Дністром і Бугом (степове Побужжя), степові території на підступах до Звенигородщини, Черкас i Канева, вся Лівобережна Наддніпрянщина i Путивльщина залишались у складі татарських улусів до другої половини 90-х pp. XIV ст.» (Яковенко, 1993: 170), що довів аналіз територіальної структури України XIV ст., проведений Ф. Петрунем на основі ханських ярликів. Так, приєднання до Києва Поросся і Звенигородщини, котрі, ймовірно, на той час входили до складу улусу Хурмадая, можна датувати приблизно вереснем 1395 p. пов’язуючи цю подію 3 вдалим походом нового київського князя Свидригайла в ординські володіння. Частина колишніх татарських земель переформувалася на литовські феоди договірним шляхом: попередні власники зберігали владу i майнові права, визнаючи вассалітет великого князя литовського. 
Нових васалів приймали як своїх. За влучним висловом Ф. Петруня, литовський уряд «лише... реєстрував ці нові утворення на своїх межах та переводив потроху тюркських династів на статус звичайних землевласників.» (Яковенко, 1993: 177). Очевидно, у такому ж положенні знаходилася, зі згаданими вище особами ханської крові, і нижча знать і рядовий військовофеодальний елемент. I ті, і другі, хоча й з різним обсягом права власності, але 3 однаковим обов'язком військової служби новому сюзерену, лишалися на тих самих землях, які займали доти (Яковенко, 1993: 172).

За ревізією Брацлавського замку 1545 р., тобто через півтора століття, бачимо тут низку власників земель на порубіжжі зі Степом безсумнівно тюркського походження. Це - Чечелі, Кордиші, Козари, Кожани, Мормули тощо (Архив Юго-Западнои России, 1890: 55). Характерно, що «старші зем'яни» Брацлавщини (пани Романовичі, Кошки, Слупиці та ін.) погордливо відхрещуються від зв'язку з більшістю згаданих родин.

Перед тим як стати «пустинею» землі Уманщини рясніли щедрими врожаями і процвітали. Й. Верещинський, маючи на увазі землі на південь і схід від Брацлава відмічав, що українські землі можуть бути житницею для інших країн, поля такі чудові - то простягаються рівнинами, то перерізаються горами і лісами, а характер їх веселий та врожайний. Тут так багато худоби, звірів, різних птахів, риби, що можна сказати - то обітована земля, яка тече молоком і медом. Вона притягує до себе людину, з якого б народу вона не виходила, як магніт залізо. І виникає це від особливості країни: небо України веселе, клімат здоровий, земля плодовита (Стороженко, 1895: 67). Уманщина на початку XVI ст. носила назву Звенигородщина, тому що охоплювала територію між Звенигородським та Брацлавським замками. Її територію тримав «у держанні» великого князя литовського князь I. Четвертинський (Ткаченко, 1927: 9). А потім Брацлав, Вінниця, Звенигородка із землями перейшли до К. Острозького, який повернувся із московського полону і був титулований у 1500 р. намісником Брацлавським, Вінницьким і Звенигородським (Яковенко, 1993: 90). Під час його полону, який стався за московсько-литовської війни, 
цією територією володів О. Сангушкович та М. Збаразький. Коли повернувся К. Острозький з полону, він знову одержав свої старі володіння. 1516 р. на прохання К.І.Острозького тримання замків було передано князеві Романові Андрієвичу Сангушковичу. В 1521 p. маємо повідомлення, що татари зруйнували Звенигородщину, можливо, що тоді зруйновано і Звенигородський замок; згодом уряд його не відновляв, дарма що населення його прохало (Ткаченко, 1927: 9). 3 цього часу Звенигородський повіт починає називатись Звенигородською пустинею, яка стала доходною статтею брацлавського старости, а також жителів Брацлава та Вінниці. Тому, як зазначав I.О. Шипович, ті, що ходили в Звенигородщину у 1552 р. «добувати мед», платили за це брацлавському старості. За полювання платили м. Вінниці по 12 грошей. Самі вінничани мали в Звенигородщині пасіки і це свідчить, що «три повета представляли собой не случайное сочетание земель, получивших название Литовского Подолия, а были одной землёй, принадлежавшей жившему на ней населению» (Шипович, 1914: 9).

Верхнім станом населення Уманщини в цей період були давні княжі роди, за ними йшли зем'яни, міщани, потім бояри. Частина бояр перейшла до зем'ян, інша до селян. Ці стани захопили собі майже всі землі. Ревізори Брацлавського замку в 1545 р. $з$ цього приводу писали: «Не знаты, где господарское, где земянское есть. Вси селыща и пожыткы на земяне и мещаны и за козаки суть» (Архив Юго-Западнои России, 1890: 58). Всі вони платили надзвичайно малі податки і виконували незначні повинності в другій половині XVI ст. тут з'явились «неведомо отколь пришедшіи люди, назвались боярами и заняли большія угодья» (Архив Юго-Западнои России, 1890: 58). Вони взагалі відмовлялись платити податки і виконувати будь-які повинності.

Як зазначає М. Ткаченко, в другій половині XVI ст. на землях уманських були володіння волинського зем'янина Семена Кошки (Ткаченко, 1927: 8). Родина Кошків між 1528 та 1545 рр. фіксується на Волині, а за ревізіями українських замків на Брацлавщині та Київщині 1545-1552 pp. і Пом’яника Києво-Печерського монастиря поміж бояр-шляхти литовсько-руського війська 
(Яковенко, 1993: 126, 148). Кошки переселилися з Волині на Брацлавщину тоді, коли будучи ще вільною від нападів татар, ця територія процвітала (Яковенко, 1993: 187).

У першій половині XVI ст., не дивлячись на напади татар, починається новий період заселення території Уманщини. 3 Волині, Київщини, Полісся та Білорусії йшли уходники, вільні добиччики, «данники», козаки. Цей колонізаційний рух на Уманщині М. Ткаченко пов’язує з загальним характером залюднення Наддніпрянщини, яке в той час уже відбувалося. Людність новоприбула єднається з козаками, що були на даній території (Ткаченко, 1927: 10).

В описі Брацлавського замку, який складав шляхтич, є відомості про місцевих жителів. Автор називає 21 сім’ю, яка входить до класу бояр, а також 14 бояр, які мали 28 дворищ названо «подлейшими», тому що невідомо від кого вони отримали свої наділи, навіть пропонується накласти на них податки (Архив Юго-Западнои России, 1890: 56). Але навіть справжні прізвища їх вказують на просте походження: Кудренко, Мишка Хорт, Митко Золотар, Комар, Козар, Дмитро Звенигородець та ін. Звісно, що для польської влади вони були небажаними і визнавати їх власниками земель, на яких вони сиділи, вона не хотіла. Тому їх не вказували в офіційних документах, стверджуючи, що «грунти Гуманський та Звенигородський»- пустощі (Кузнець, 2000: 87). Але ж це не так, тому що вже в другій третині XVI ст. джерела зазначають, що на території краю існувало кілька поселень. Серед них - Буки, Вороне, Мошурів, Романівка, Соколівка, Торговиця. Всі вони, крім Торговиці позначаються на так званому Звенигородському грунті, в північній або східній частині Гуманщини (Ткаченко, 1927: 10). Згадуються також в цей час поселення Саврань (Собранъ) та Гайсин (Айсынъ) (Архив Юго-Западнои России, 1890: 55), що знаходились на заході Уманщини.

Інформації про власників цих населених пунктів обмаль. Серед перших на Звенигородщині, тобто Уманщині, називається Степан Базанович, який із своїм братом Федором на 1542 р. володів селами Романівкою та Демковцями, а в 
1545 р. ці села з придатком Ягубця перейшли до Козара (Архив Юго-Западнои России, 1890: 57).

Населеними пунктами Вороним та Соколівкою володів з 1545 по 1592 pp. козак звенигородський Дмитро Базанович, а в другій половині століття він самовільно зайняв землі і на них заснував поселення Буки (Архив ЮгоЗападнои России, 1890: 57). В «Реєстрах найманого війська на землях Русі й Поділля» та переписі загону прикордонної сторожі за 1529 р. ми бачимо, як зазначають I.I. Кривошея та Iр.I. Кривошея, Дмитра Базановича-Звинигородця (Кривошея, Кривошея, 2000: 81).

В описі брацлавського замку (1545р.) містяться також відомості про поселення Мушурів, яке також зазначається на грунтах звенигородських (Архив Юго-Западнои России, 1890: 55). Власником Мушурова в цей період зафіксований зем’янин Митко Золотар (Ткаченко, 1927: 11).

I Базанович (Базанович-Звинигородець), i Золотар (Золотаренко) зустрічається серед панів і бояр-шляхти по ревізіях українських замків на Брацлавщині та Київщині 1545-1552 рр. (Кривошея, Кривошея, 2000: 81). В описах брацлавського замку зазначається, що зем'яни мають багато пасік, городів, садів, орних полів тощо (Архив Юго-Западнои России, 1890: 21-23). В.О. Щербак пише про схильність зем'янина Д. Базановича до козацького промислу, «адже в документах за 1529 р. він згадується серед охоронців державного кордону поблизу Саврані, Чечельника, Звенигорода, Кошиловців» (Щербак, 1997: 73). Синові Дмитра - Богданові, який продовжував іменуватися козаком, королева Бона в 1549 р. надала ще й селище Курилівці, хоча відомостей про його козакування не збереглося.

У кінці XVI ст. всі вище згадані населені пункти були куплені в 1592 р. у онука Базановичів, Федора Богдановича, та Золотарів галицьким каштеляном Ю. Струсем (Щербак, 1997: 73), який пізніше переписав їх на свого зятя Валенту-Александра Калиновського.

Висновки. Отже, турецько-татарська агресія несла українському народові смертельну загрозу винищення, втрати економічної та господарської 
самостійності. І чи не найбільше в цьому страждало порубіжне населення. Саме тут, на Уманщині, вторгнення татар та турків супроводжувалося найжорстокішим розоренням міст та сіл, винищенням і вигнанням у рабство великих мас населення.

Вирішальну роль в організації відсічі турецько-татарським нападам відіграло населення Уманщини. Займаючись хліборобством, скотарством, рибальством, полюванням, ремеслами, засновуючи нові хутори i села, створюючи нові і піднімаючи з руїн знищені міста, воно водночас було готовим дати відсіч турецько-татарським нападам. Саме воно стало основою козацтва, обростаючи втікачами з різних земель.

У другій половині XV - першій половині XVI ст. починається новий період заселення території нашого краю. Не дивлячись на напади татар, відбувається залюднення території уходниками, вільними добиччиками, «данниками», козаками, що йшли з Волині, Київщини, Полісся та Білорусії.

\section{СПИСОК ВИКОРИСТАНИХ ДЖЕРЕЛ І ЛІТЕРАТУРИ}

Антонович, 1888 - Антонович В. Грановщина. (Эпизод из истории Брацлавской Украины). Киев: Тип. Г.Т. Корчак-Новицкаго. 19 с. (Оттиск из журнала «Киевская старина». Т. ХX, 1888 г. январь-март. С. 75-95).

Апанович, 1961 - Апанович О. Запорізька Січ у боротьбі проти турецько-татарської агресії 50-70-ті роки XVII ст. К.: Вид-во АН УРСР, 1961. 299 с.

Архив Юго-Западной России, 1890 - Архив Юго-Западной России, изданный временною комиссиею для разбора древних актов, высочайше утверждённую при Киевском военном, Подольском и Волынском генералгубернаторе. Ч. VII. Т. 2. К., 1890. 859 с.

Вышневский, 1930 - Вышневский В. Феодализм в Крымском ханстве. М.: Наука, 1930. 267 с.

Волошенко, 1995 - Волошенко І. Монастирищина: 3 історії рідного краю. Черкаси, 1995. 136 с.

Грушевський, 1993 - Грушевський М. С. Історія України-Руси. В 11 т., 12 кн. / Редколегія: П. С. Сохань (голова) та ін. Т. 4. К.: Наукова думка, 1993. 544 с.

Єфименко, 1919 - Сфименко О. Татарські напади. К.: Вид. Укр. академ. наук, 1919. 76 с.

Історія України, 1997 - Історія України / В. Ф. Верстюк, О. В. Гарань, О. І. Гуржій та ін.; Під ред. В. А. Смолія. К.: Альтернативи, 1997. 416 с.

Історія України, 1995 - Історія України: нове бачення: у 2-х т. / О. І. Гуржій, Я. Д. Ісаєвич, М.Ф. Котляр та ін.; Під. ред. В.А. Смолія. Т. 1. К.: Україна, 1995. 350 с.

История Украинской ССР, 1981 - История Украинской ССР. В 10-ти томах. / Ред. Кол.: Ю. Ю. Кондуфор (главный редактор), И. И. Артеменко и др. Т. 1. Первобытнообщинный строй и зарождение классового общества. Киевская Русь (До второй половины XIII в.). К.: Наукова думка, 1981. 495 с.

Кащенко, 1991 - Кащенко А. Оповідання про славне Військо Запорозьке Низове. Дніпропетровськ: Січ, 1991. $494 \mathrm{c}$.

Київський літопис, 1989 - Київський літопис. К.: Дніпро, 1989. 537 с.

Кісь, 1986 - Кісь Я. Татарські шляхи на Україні в XVI-XVII ст. // Жовтень. 1986. № 4. С. 134-136.

К. И. Т-ый, 1888 - К. И. Т-ый. Краткий очерк истории г. Умани // Киевская Старина. 1888. Т. ХХІІ. Авг. С. 381-394.

Кривошея I. I., Кривошея Ip. I., 2000 - Кривошея I. I., Кривошея Iр. I. Уманщина в XIV - XVI ст. // Гуманітарні науки: проблеми, пошуки, перспективи. Збірник наукових пращь. Частина VI. / Редкол: В. Г. Кузь (голов ред.) та ін. К.: Знання, 2000. С. 79-83. 
Кузнець, 2000 - Кузнець Т. В. Уманщина в польсько-литовську добу (XIV - перша половина XVIII ст.). // Гуманітарні науки: проблеми, пошуки, перспективи. Збірник наукових праџь. Частина VI. / Редкол: В. Г. Кузь (голов ред.) та ін. К.: Знання, 2000. С. 83-91.

Молчановский, 1886 - Молчановский Н. Очерк известий о Подольской земле. Киев, 1886. 320 с.

Описание Чёрного моря, 1992 - Описание Чёрного моря и Татарии (Сост. доминиканец Эмилио Дортелли д. Асколи префект Кафы, Татарии и проч. Т. 24. Одесса. 1992. 328 с.

Османская империя, 1984 - Османская империя в первой четверти XVII в.: Сб. документов и материалов / Сост. Имрагимбейли, Н.С.Рашба. М.: Наука, 1984. 213 с.

Панашенко, 1989 - Панашенко В. Кримське ханство у XVI-XVIII ст. // Украӥнський історичний журнал. 1989. № 1. С. 54-64.

Полное собрание русских летописей, 1962 - Полное собрание русских летописей издаваемое постоянной историко-археографической комиссией АН СССР. Т. 2. Ипатская летопись. М.: Изд. восточ. лит., 1962. XVI, 938, $87 \mathrm{c.}$

Сборник летописей, 1888 - Сборник летописей, относящихся к истории Южной и Западной Руси / Изд. В. Антонович. К.: Тип. Г. Т. Корчак-Новицкого, 1888. II + LIX + 322 с.

Стороженко, 1895 - Стороженко А. В. Малоизвестные сочинения Киевского бискупа (1589-1598) Иосифа Верещинского. К.: Тип. Н. Т. Новицкого, 1895. 96 с.

Супральская рукопись, 1836 - Супральская рукопись. М.: Изд. Общества истории и древностей России, 1836.32 c.

Терлецький, 1930 - Терлецький О. Україна заборолом культури й цивілізації перед степовиками. Львів: Вид. «Просвіти», 1930. 91 с.

Ткаченко, 1927 - Ткаченко М. Гуманщина в XVI-XVIII вв. К.: УАН, 1927. 32 с.

Чабан, 1999 - Чабан А. Ю. Середнє Подніпров’я. Книга 2. Черкаси: РВВ ЧДУ, 1999. 177 с.

Чумак , 1992 - Чумак В. Кримське ханство і Запоріжжя: шлях від ворожнечі до взаєморозуміння // Голос України. 1992. № 110.

Шипович, 1914 - Шипович И. О. О границах бывшей Брацлавщины, исторической жизни в ней и отношении Брацлавщины к Подолии. Винница: Тип. Городского управления, 1914. 24 с.

Щербак, 1997 - Щербак В. О. Формування козацького стану в Україні (друга половина XV-XVII ст.). К.: Наукова думка, 1997. 180 с.

Якобсон, 1973 - Якобсон А. Крым в средние века. М.: Наука, 1973. 173 с.

Яковенко, 1993 - Яковенко Н. М. Українська шляхта 3 кінця XIV до середини XVII ст.: (Волинь і Центральна Україна). К.: Наукова думка, 1993. 416 с.

\section{REFERENCES}

Antonovich, 1888 - Antonovich V. Granovshchina [Granovshchina. (An episode from the history of Bratslav Ukraine)]. (Epizod iz istorii Bratslavskoy Ukrainy). Kiev: Tip. G.T. Korchak-Novitskago. 19 s. (Ottisk iz zhurnala «Kievskaya starina». T. KhKh, 1888 g. yanvar-mart. S. 75-95). [in Russian].

Apanovych, 1961 - Apanovych O. Zaporizka Sich u borotbi proty turetsko-tatarskoi ahresii 50-70-ti roky XVII st. [Zaporizhzhya Sich in the struggle against Turkish-Tatar aggression in the 50-70s of the XVII century]. K.: Vyd-vo AN URSR, 1961. 299 s. [in Ukrainian].

Arkhiv Yugo-Zapadnoy Rossii, 1890 - Arkhiv Yugo-Zapadnoy Rossii, izdannyy vremennoyu komissieyu dlya razbora drevnikh aktov, vysochayshe utverzhdennuyu pri Kievskom voennom, Podolskom i Volynskom general-gubernatore [Archive of South-Western Russia, published by the temporary commission for the analysis of ancient acts, the highest approved by the Kiev military, Podolsk and Volyn governor-general]. Ch. VII. T. 2. K., 1890. 859 s. [in Russian]. Vyshnevskiy, 1930 - Vyshnevskiy V. Feodalizm v Krymskom khanstve [Feudalism in the Crimean Khanate]. M.: Nauka, 1930. 267 s. [in Russian].

Voloshenko, 1995 - Voloshenko I. Monastyryshchyna: Z istorii ridnoho kraiu [Monastyryshchyna: From the history of the native land]. Cherkasy, 1995. $136 \mathrm{~s}$. [in Ukrainian].

Hrushevskyi, 1993 - Hrushevskyi M. S. Istoriia Ukrainy-Rusy [History of Ukraine-Russia]. V 11 t., 12 kn. / Redkolehiia: P. S. Sokhan (holova) ta in. T. 4. K.: Naukova dumka, 1993. 544 s. [in Ukrainian].

Yefymenko, 1919 - Yefymenko O. Tatarski napady [Tatar attacks]. K.: Vyd. Ukr. akadem. nauk, 1919.76 s. [in Ukrainian].

Istoriia Ukrainy, 1997 - Istoriia Ukrainy [History of Ukraine] / V.F. Verstiuk, O.V. Haran, O.I. Hurzhii ta in.; Pid red. V.A. Smoliia. K.: Alternatyvy, 1997. 416 c. [in Ukrainian].

Istoriia Ukrainy, 1995 - Istoriia Ukrainy: nove bachennia: u 2-kh t. [History of Ukraine: a new vision] / O.I. Hurzhii, Ya.D. Isaievych, M.F. Kotliar ta in.; Pid. red. V.A. Smoliia. T. 1. K.: Ukraina, 1995. 350 s. [in Ukrainian].

Istoriya Ukrainskoy SSR, 1981 - Istoriya Ukrainskoy SSR [History of the Ukrainian SSR]. V 10-ti tomakh. / Red. Kol.: Yu.Yu. Kondufor (glavnyy redaktor), I.I. Artemenko i dr. T. 1. Pervobytnoobshchinnyy stroy i zarozhdenie klassovogo obshchestva. Kievskaya Rus (Do vtoroy poloviny KhIII v.). K.: Naukova dumka, 1981. 495 s. [in Russian].

Kashchenko, 1991 - Kashchenko A. Opovidannia pro slavne Viisko Zaporozke Nyzove [The story of the glorious Zaporozhian Lowland Army]. Dnipropetrovsk: Sich, 1991. 494 s. [in Ukrainian]. 
Kyivskyi litopys, 1989 - Kyivskyi litopys [Kyiv Chronicle]. K.: Dnipro, 1989. 537 s. [in Ukrainian].

Kis, 1986 - Kis Ya. Tatarski shliakhy na Ukraini v XVI-XVII st. [Tatar ways in Ukraine in the XVI-XVII centuries] // Zhovten. 1986. № 4. S. 134-136. [in Ukrainian].

K. I. T-yy, 1888 - K. I. T-yy. Kratkiy ocherk istorii g. Umani [A brief outline of the history of Uman] // Kievskaya Starina. 1888. T. KhKhII. Avg. S. 381-394. [in Russian].

Kryvosheia I. I., Kryvosheia Ir. I., 2000 - Kryvosheia I. I., Kryvosheia Ir. I. Umanshchyna v XIV - XVI st. [Uman region in the XIV-XVI centuries] // Humanitarni nauky: problemy, poshuky, perspektyvy. Zbirnyk naukovykh prats. Chastyna VI. / Redkol: V. H. Kuz (holov red.) ta in. K.: Znannia, 2000. S. 79-83. [in Ukrainian].

Kuznets, 2000 - Kuznets T. V. Umanshchyna v polsko-lytovsku dobu (XIV - persha polovyna XVIII st.). [Uman region in the Polish-Lithuanian era (XIV - first half of the XVIII century)] // Humanitarni nauky: problemy, poshuky, perspektyvy. Zbirnyk naukovykh prats. Chastyna VI. / Redkol: V. H. Kuz (holov red.) ta in. K.: Znannia, 2000. S. 8391. [in Ukrainian].

Molchanovskiy, 1886 - Molchanovskiy N. Ocherk izvestiy o Podolskoy zemle [Sketch of news about the Podolsk land]. Kiev, 1886. 320 s. [in Russian].

Opisanie Chernogo morya, 1992 - Opisanie Chernogo morya i Tatarii [Description of the Black Sea and Tartary] (Sost. dominikanets Emilio Dortelli d. Askoli prefekt Kafy, Tatarii i proch. T. 24. Odessa. 1992. 328 s. [in Russian].

Osmanskaya imperiya, 1984 - Osmanskaya imperiya v pervoy chetverti XVII v. [Ottoman Empire in the first quarter of the 17th century]: Sb. dokumentov i materialov / Sost. Imragimbeyli, N.S.Rashba. M.: Nauka, 1984. 213 s. [in Russian]. Panashenko, 1989 - Panashenko V. Krymske khanstvo u XVI-XVIII st. [Crimean Khanate in the XVI-XVIII centuries] // Ukrainskyi istorychnyi zhurnal. 1989. № 1. S. 54-64. [in Ukrainian].

Polnoe sobranie russkikh letopisey, 1962 - Polnoe sobranie russkikh letopisey izdavaemoe postoyannoy istorikoarkheograficheskoy komissiey AN SSSR [Complete collection of Russian chronicles published by the permanent historical and archaeographic commission of the USSR Academy of Sciences]. T. 2. Ipatskaya letopis. M.: Izd. vostoch. lit., 1962. XVI, 938, 87 s. [in Russian].

Sbornik letopisey, 1888 - Sbornik letopisey, otnosyashchikhsya k istorii Yuzhnoy i Zapadnoy Rusi [Collection of chronicles related to the history of Southern and Western Russia] / Izd. V. Antonovich. K.: Tip. G. T. KorchakNovitskogo, 1888. II + LIX + 322 s. [in Russian].

Storozhenko, 1895 - Storozhenko A. V. Maloizvestnye sochineniya Kievskogo biskupa (1589-1598) Iosifa Vereshchinskogo [Little-known works of the Kiev bishop (1589-1598) by Joseph Vereshchinsky]. K.: Tip. N. T. Novitskogo, 1895. 96 s. [in Russian].

Supralskaya rukopis, 1836 - Supralskaya rukopis [Supral manuscript]. M.: Izd. Obshchestva istorii i drevnostey Rossii, 1836. 32 s. [in Russian].

Terletskyi, 1930 - Terletskyi O. Ukraina zaborolom kultury y tsyvilizatsii pered stepovykamy [Ukraine is a ban on culture and civilization before the steppes]. Lviv: Vyd. «Prosvity», 1930. 91 s. [in Ukrainian].

Tkachenko, 1927 - Tkachenko M. Humanshchyna v XVI-XVIII vv. [Humanity in the XVI-XVIII centuries]. K.: UAN, 1927. 32 s. [in Ukrainian].

Chaban, 1999 - Chaban A. Yu. Serednie Podniprovia [Middle Dnieper]. Knyha 2. Cherkasy: RVV ChDU, 1999.177 s. [in Ukrainian].

Chumak , 1992 - Chumak V. Krymske khanstvo i Zaporizhzhia: shliakh vid vorozhnechi do vzaiemorozuminnia [Crimean Khanate and Zaporozhye: the path from enmity to mutual understanding] // Holos Ukrainy. 1992. № 110. [in Ukrainian].

Shipovich, 1914 - Shipovich I. O. O granitsakh byvshey Bratslavshchiny, istoricheskoy zhizni v ney i otnoshenii Bratslavshchiny $\mathrm{k}$ Podolii [On the borders of the former Bratslav region, historical life in it and the attitude of the Bratslav region to Podolia]. Vinnitsa: Tip. Gorodskogo upravleniya, 1914. 24 s. [in Russian].

Shcherbak, 1997 - Shcherbak V. O. Formuvannia kozatskoho stanu v Ukraini (druha polovyna XV-XVII st.) [Formation of the Cossack state in Ukraine (second half of the XV-XVII centuries)]. K.: Naukova dumka, $1997.180 \mathrm{s.}$ [in Ukrainian].

Yakobson, 1973 - Yakobson A. Krym v srednie veka [Crimea in the Middle Ages]. M.: Nauka, 1973. 173 s. [in Russian].

Yakovenko, 1993 - Yakovenko N. M. Ukrainska shliakhta z kintsia XIV do seredyny XVII st.: (Volyn i Tsentralna Ukraina) [Ukrainian gentry from the end of the 14th to the middle of the 17th century: (Volyn and Central Ukraine)]. K.: Naukova dumka, 1993. 416 s. [in Ukrainian]. 